IRYNA L. KRAVCHENKO

Kiev National University of Construction and Architecture

e-mail: kravchenko.il@knuba.edu.ua
Manuscript submitted 2019.08.07 - revised 2019.09.12 initially accepted for publication 2019.09.30, published in September 2019

\title{
EXTERNAL AND INTERNAL FACTORS OF INFLUENCE ON DEVELOPMENT OF ARCHITECTURE OF NON-FORMAL EDUCATION ESTABLISHMENTS
}

\section{ZEWNĘTRZNE I WEWNĘTRZNE CZYNNIKI WPŁYWAJĄCE NA ROZWÓJ ARCHITEKTURY PRZEDSIĘBIORSTW EDUKACYJNYCH}

DOI: $10.30540 /$ sae-2019-013

\begin{abstract}
The article sets out the main provisions on internal and external factors of influence on the development of architecture of non-formal education institutions. External factors are represented by a group of socio-economic factors, a technical (technological) factor, a number of political factors and an environmental factor. Internal factors that influence the development of the architecture of educational institutions include urban planning, architectural-planning, naturalclimatic, and aesthetic. The article also presents the brief analysis of architectural projects done abroad and at the Theory of Architecture Department of Kyiv National University of Construction and Architecture to illustrate the impact of factors and to show main trends of architectural development of modern educational buildings.
\end{abstract}

Keywords: non-formal education, institutions of non-formal education, external and internal factors of influence, development trends of architecture for educational institutions

\begin{abstract}
Streszczenie
$W$ artykule określono glówne elementy dotyczace wewnętrznych i zewnętrznych czynników wplywajacych na rozwój architektury pozaformalnych instytucji edukacyjnych. Czynniki zewnętrzne reprezentowane sa przez grupę czynników spoteczno-ekonomicznych, czynnik techniczny (technologiczny), szereg czynników politycznych i czynnik środowiskowy. Czynniki wewnętrzne, które wplywaja na rozwój architektury instytucji edukacyjnych, obejmuja planowanie urbanistyczne, architektoniczne, przyrodniczo-klimatyczne i estetyczne. W artykule przedstawiono również krótka analizę projektów architektonicznych wykonanych za granica oraz w Katedrze Teorii Architektury Kijowskiego Narodowego Uniwersytetu Budownictwa i Architektury w celu zilustrowania wpływu czynników i ukazania głównych trendów rozwoju architektonicznego nowoczesnych budynków edukacyjnych.
\end{abstract}

Słowa kluczowe: edukacja pozaformalna, instytucje edukacji pozaformalnej, zewnętrzne i wewnętrzne czynniki wpływu, trendy rozwojowe architektury instytucji edukacyjnych

\section{INTRODUCTION}

Comprehensive interdisciplinary studies of factors affecting the development of the architecture of nonformal educational institutions cover a rather wide range of issues. Since non-formal education is an open educational subsystem, specialists from various sectors are involved in researching the problems of its formation and development, covering the problem from different perspectives: sociologistic, educational, historic, economic, statistical, etc. From the indicated branches accompanying the current research, basic concepts are borrowed concerning factors of influence and prerequisites for the development of non-formal educational institutions and are analyzed in accordance with the object of research. The object of this study is the institution of non-formal education. The subject of the research is the theoretical foundations of the formation of 
architecture of non-formal educational institutions in Ukraine and the modern world. Identification of the main factors of influence is one of the most important tasks in the context of the study.

Specialists from different countries dealt with the pedagogical and psychological problems of the formation and development of out-of-school and nonformal education. Joe Cullen, British psychologist noted that main factors are shaping lifelong learning are historical, demographic changes, globalisation and economic re-structuring, cultural changes, information and communications technology (ICT) and social networking [1]. Among Ukrainian specialist teachers, a lot of attention is paid to the development of out-of-school education as a part of the education process throughout life. So, doctor of pedagogical sciences Bykovskaya O.V. in her monograph presents the theoretical and methodological foundations of the formation of out-of-school education, based on the introduction of a competency-based approach [2]. The works of Nadezhda Pavlik highlight the theoretical and practical foundations of the organization of nonformal youth education. The analysis of pedagogical scientific literature conducted by Pavlik N. indicates that the organization of non-formal education is an important socio-political task for the most of developed countries. In addition, she emphasizes that non-formal education in Ukraine includes: outof-school education, postgraduate education and adult education, civic education, school and student self-government, educational initiatives aimed at developing additional skills (computer and language courses, interest groups etc.), as well as the education of the elderly [3]. The work of Chagrak N. is devoted to the influence of demographic and socio-economic factors on the education of older people [4]. Basic sociological concepts, such as the social structure of society, which is a part of the socio-economic factor, are highlighted in the works of Verbets V.V., Subot O.A., Khristyuk T.A. [5]. Economists note the increasing role of human capital as one of the driving forces for the development of various levels of additional education [6].

Problems of development of the architecture of different level and purpose educational institutions are dealt with by architects-scientists.

Jeffery A. Lackney, architect $\mathrm{PhD}$ from American Institute of Architect (AIA), studying design principles for schools and community learning centres says: "A variety of social and economic factors have created an environment in which many educators recognize that learning happens all the time and in many different places. Formal educational program partnerships have been established with museums, zoos, libraries, other public institutions, as well as in local business workplace settings. Sharing school facilities with a variety of community organizations may fostering meaningful inter-organizational partnerships that can strengthen educational opportunities for learners." [7]. Lindsay Baker, the American architect who studies development of school architecture noted that schools are influenced by political and social movements, new technologies and trends, the growing awareness of what makes us learn better and thus our notions of what makes a great school are constantly shifting and adapting to new ideas [8]. Habibe Acar pointed out that main impact on learning process is learning environment. The scientist underlines the importance of the notions of environment and learning environments that influence especially the development of children and his study touches on the contributions of the physical environment to the learning process of children [9].

Russian architects-scientists Zmeul S.G., Tsitovich G.M., Stepanov V.I., and Ukrainian specialists Kovalsky L.M., Abyzov V. A., Naumov S.F., Sarkisov S.K., Smirnov V.V., Solobay P.A., Zhovkva O.I., Kovalskaya G.L., Merilova I.O., Tyshkevich O.P. and others also thoroughly dealt with the problems of the influence of various factors on the formation of architectural objects and educational complexes for various purposes. Among the factors influencing the development of architecture of educational buildings, socio-economic and socio-demographic conditions, the political factor, scientific and technological progress, historical-cultural and material-technical factors and the like are defined. Based on his own research, Abizov V.A. identifies the following groups of factors that determine sustainable development, such as: socio-economic; natural-geographical; urban; environmental; ergonomic; typological; technical; aesthetic $[10,11]$.

\section{BASIC THEORY}

During the study of the problems of formation of the architecture of non-formal education institutions (NFEI), a number of main factors affecting its development were identified. Factors are conventionally grouped into external and internal (Fig. 1). External factors are, as a rule, forces uncontrolled by the architect, which to a certain extent form a public demand for the creation of a new 
type of educational objects and, thus, influence the formation of the architecture object. External factors include: socio-economic, technical, political and environmental. Internal factors determine a number of regulatory, environmental and functional changes and requirements for the structure of educational buildings. The internal factors of influence on the development of architecture of educational institutions of various types and purposes include the following; town planning factor, architectural planning, climatic and aesthetic (Fig. 1).

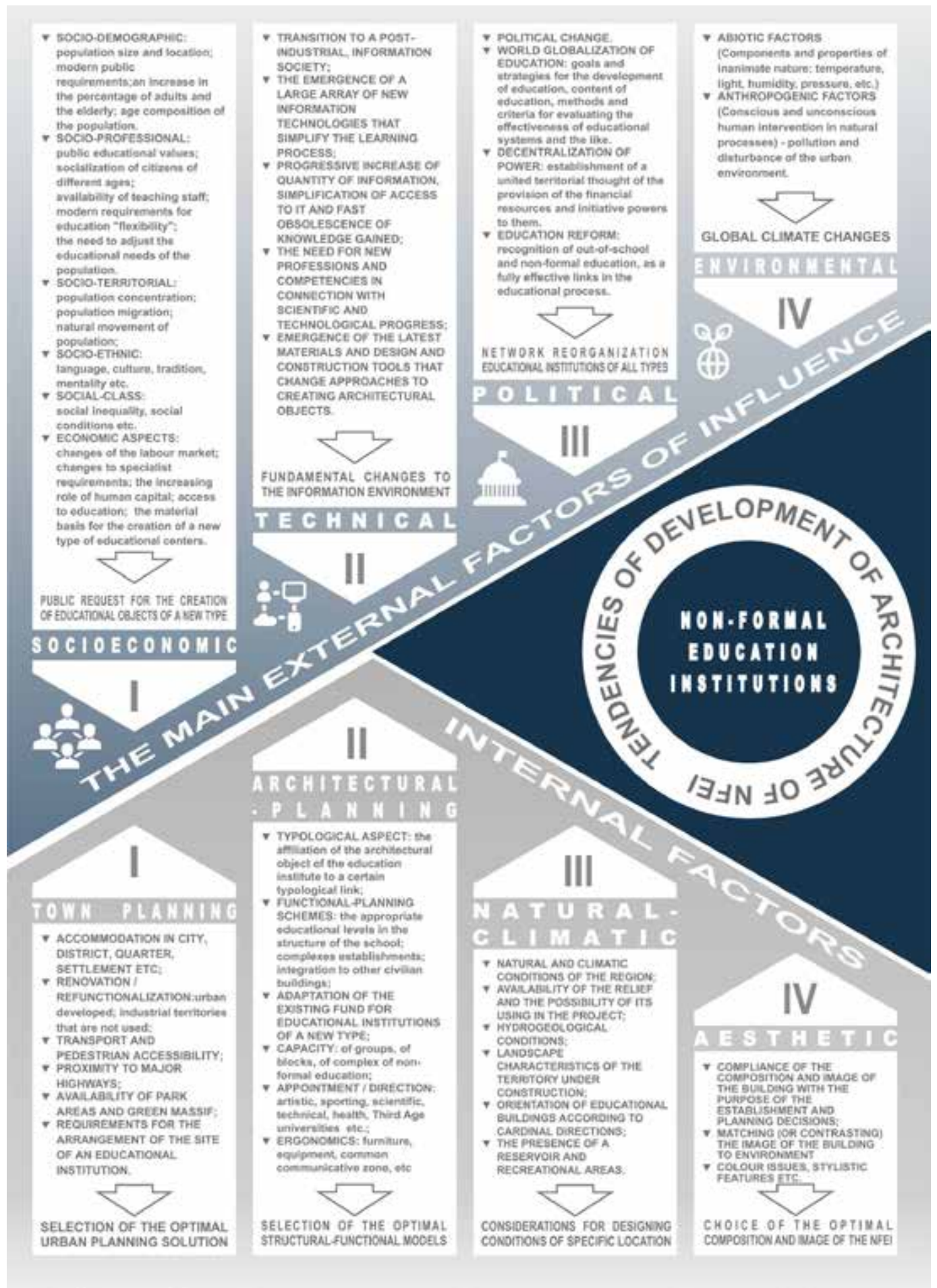

Fig. 1. Basic scheme of the impact of external and internal factors on the development of architecture of non-formal education institutions.

Source: the scheme developed by Iryna L. Kravchenko according to own research results. 
External factors of influence. Among the main external factors in terms of the importance of influence, the first place is occupied by the socio-economic factor. It consists of the following conceptual subgroups: socio-ethnic structure, socio-demographic structure, socio-professional structure, social class and socio-territorial structure [5]. The author of the article already studied impact of socio-economic factor on architectural formation of non-formal educational institution buildings [12]. The study revealed that the most influential factors of this subgroup are: socio-demographic, which signals an increase in the proportion of adults and older people, against the background of a decline in the total population in the demographic composition of Ukraine; socioprofessional, which is closely related to the problem of socialization of all segments of the population; socioterritorial, in fact, claims to strengthen the process of urbanization and requires the creation of an extensive network of non-formal education institutions by type, location and capacity; economic, which, in turn, is closely connected with the other positions listed above and speaks of the increasing role of human capital both in Ukraine and abroad.

External demographic reasons, first of all, include the demographic situation. The number of students is declining, the principles of their resettlement are changing, and new micro-districts are being built, where mainly young families move, which affects the increase in the number of students. At the same time, the centers of cities where the educational infrastructure is most developed are aging, very few children remain there. This trend is applicable to all cities of Ukraine, therefore, a thorough review of the functioning of all education networks is required: both preschool, and general, and additional, and vocational education and cultural institutions, the creation of network base institutions with branches. Thus, external causes drive new solutions [13].

Modern research by sociologists and educators suggests that now the structure of a person's life path is changing significantly. For example, cand. ped. sciences Chagrak N., analyzing the influence of demographic and socio-economic factors on the development of older people's education in the USA, notes that in addition to the aging of the nation, the so-called "blended life plan" has become another significant factor in the development of older people's education, which, in turn, was the result of demographic, social, and technological transformations in American society [4] (Fig. 2).

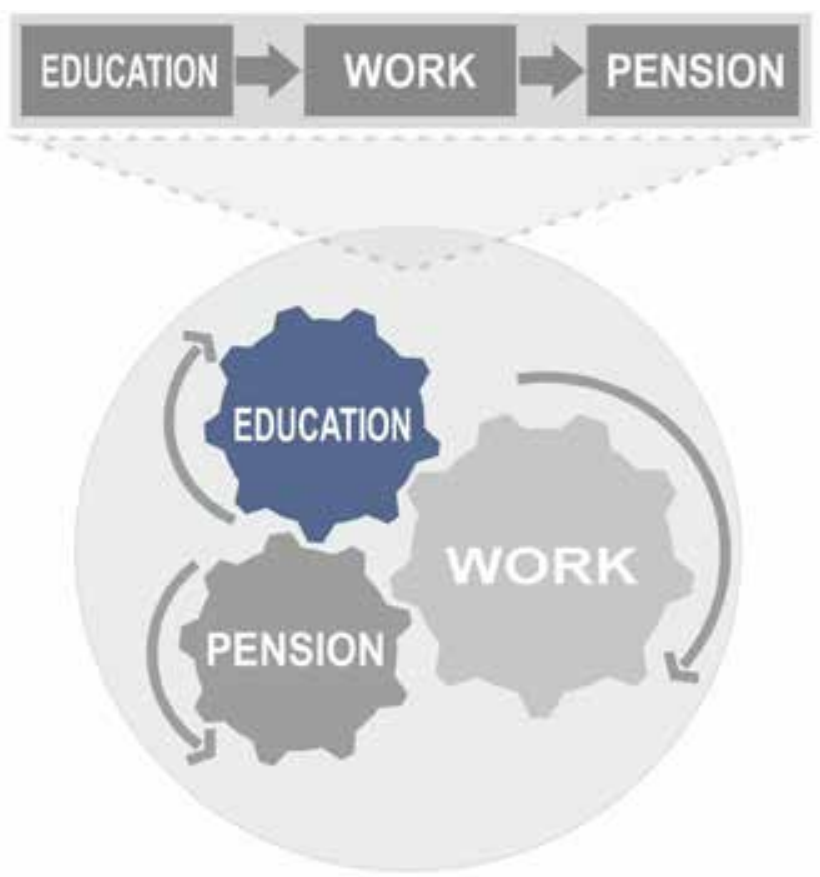

Fig. 2 Transformation of three-component structure of human's way of life.

Source: the scheme developed by Iryna L. Kravchenko according to [4].

Such a tendency is also inherent in other countries and, gradually, is finding its ways in Ukraine. Among the economic components of this factor, the role of human capital is the most prominent. Human capital is a combination of qualities (knowledge, abilities, desires, motives, skills, psychophysical state, etc.) that are innate and acquired through investments in personal development, the implementation of which serves as a competitive advantage in the global labour market and is a source of additional profit [14]. In the modern world, countries that we call developed, give priority to investments in human capital. In the structure of the national wealth of the world community, it already makes $64 \%$, ahead of natural capital (20\%) and physical capital (16\%). The share of human capital in countries such as Finland, Switzerland, Germany, Japan, and the United States reaches $80 \%$. Human capital is a determining factor in the development of production, the introduction of new technologies; it ensures the rapid development of science and high social standards (culture, health, safety, and social protection). A special area of social life, due to which there is an increase in human capital, is the scientific and educational industry [6].

In general, the socio-economic factor determines the emergence of a public demand for the creation of a new type of educational environment, and, at the 
same time, of educational objects. The architecture of non-formal education institutions should reflect the public's commitment to the flexibility of educational scenarios and their corresponding spaces.

The second most important influence is the technical (or technological) factor. This group of factors includes the following concepts:

- Transition to a post-industrial, information society;

- The emergence of a large array of the latest information technologies that simplify learning processes;

- A progressive increase in the amount of information, simplification of the way to access it and the rapid obsolescence of acquired knowledge;

- The urgent need for new professions and competencies in connection with scientific and technological progress;

- The emergence of the latest materials, design and construction tools that change approaches to the creation of architectural objects.

All this leads to fundamental changes in the information environment.

The next, third factor from the group of external factors, is the political factor. The author puts the following aspects into this concept:

- Changes in political structure.

- Globalization of education in the world: goals and strategies for the development of education, the content of education, methods and criteria for evaluating the effectiveness of educational systems, and the like.

- Decentralization of power, the creation of united territorial communities. Providing them with financial resources and initiative powers.

- Education reform. Recognition of extracurricular and non-formal education as full-fledged links in the educational process.

Changes in the political system significantly affect the formation of architecture of educational institutions - from the era of totalitarianism, where monumental, static, centric and symmetrical compositional schemes prevailing, embodying the political idea, to modern architecture, with its various compositional forms, atriums, and the inclusion of the environment in the institution's function, which symbolizes openness and willingness to learn new things. The concept of globalization of education is derived from the concept of globalization, used in economic, political and social sciences since the beginning of the $90 \mathrm{~s}$. XX century. Globalization is a complex and baffling phenomenon.
The political aspect of the impact of globalization on the development of education is determined by the spread of the ideas of neoliberalism on the educational policy of a significant number of states, and has the following manifestations: 1) erosion of the sovereignty of the nation state and the fullness of its authority in the field of educational policy, increased influence on the educational policy of international organizations (World Bank, World Bank Organization, International Monetary Fund); 2) denationalization of the educational sphere, privatization of educational services; 3 ) the transformation of forms of control in the field of education: from political, administrative to market, consumer control. The influence of the economic aspect of globalization on the development of education lies in its transformation into the subject of international trade. Another dimension of the impact of globalization on modern education is culture. In their totality, the political, economic and cultural aspects of the impact of globalization on the development of education make it possible to talk about the emergence of the phenomenon of globalization of education, by which we mean the process of convergence of the fundamental principles of the educational policy of national states in a number of parameters, primarily such as goals and strategies for the development of education, educational content, methods and criteria for evaluating the effectiveness of educational systems and the like. The concept of globalization of education was included in Ukrainian pedagogical science at the beginning of the XXI century in the context of studies of global educational policy and determination of strategic directions for reforming the educational system of Ukraine [15]. It is this factor that most critically affects the reorganization of the network of educational institutions of all types.

The fourth externall factor is environmental. It includes: abiotic factors - components and properties of inanimate nature: temperature, illumination, humidity, pressure, etc.; anthropogenic factors - conscious and unconscious human intervention in natural processes, pollution and disturbance of the urban environment. These aspects, in the end, cause global climate change, which, in turn, directly affects the creation of architectural objects, especially their structural and engineering components.

Internal factors of influence. Internal factors that influence the development of architecture of nonformal educational institutions (NFEI) include: townplanning, architectural-planning, natural-climatic and compositional-shaped (see Fig. 1). 
The first of these is the town-planning factor, which is as follows:

- Location: in the city, district, quarter, village and the like;

- Renovation/re-functionalization: prevailing urban development; industrial areas that are not used;

- Transport and pedestrian accessibility;

- Proximity to major highways;

- The presence of park areas and green spaces;

- Requirements for the arrangement of a site for an educational institution.

Consideration of all these aspects should contribute to the selection of the optimal urban planning decision on the placement of the architectural object of the educational institution.

The second factor of this group is architecturalplanning. This internal factor of influence requires a balanced approach to the choice of architectural and planning solutions of the latest NFEI. The main aspects of this factor are:

- Typological aspect: the affiliation of the architectural object of the education institute to a certain typological link;

- Functional planning schemes: the corresponding educational level in the structure of the school, integrated institutions, integration into other public complexes;

- Adaptation of the existing fund for an educational institution;

- Capacity: groups, blocks, non-formal education complexes, etc;

- Appointment/direction: art, sports, scientific and technical, health, universities of the third age and the like;

- Ergonomics: furniture, equipment, general communication areas and the like.

The result of competent processing of factors of this group should be the optimal structural and functional models of institutions of the NFE and their cells, different in capacity and purpose.

The third factor from the internal factors of influence is the natural-climatic one. It includes several aspects: the climatic conditions of the region, the presence of relief and the possibility of its use in the project, hydrogeological conditions, landscape characteristics of the developed territory, the orientation of the educational institution, the presence of reservoirs and recreational areas. This factor obliges to consider when designing the conditions of a particular area.
The fourth factor is aesthetic and it is represented by three main aspects: the correspondence of the composition and image of the building to the purpose of the institution and the planning decision, the correspondence (or opposition) of the image of the building to the environment, and the colour issues, stylistic features etc. With a balanced approach to the design of NFEI, the consequence should be the choice of the optimal composition and image of the building of a non-formal educational institution.

\section{RESULTS AND DISCUSSION}

Solving the problems of our time, due to external and internal factors of influence, the architecture of non-formal education institutions is developing and creates certain trends in the design of institutions of additional education. The Department of Theory of Architecture of KNUCA (Kyiv National University of Construction and Architecture) conducts research in the field of theoretical foundations of architecture of public buildings and complexes (No. 67.01.18.0768/0117U005420) [16]. Within the framework of the current study, a number of major trends in the development of NFEI (non-formal education institutions) architecture were identified (Fig. 3).

The first and most important trend is cooperation. The trend is formed under the influence of a number of the above factors: socio-economic, political, environmental, urban planning, architectural-planning, with a review of the typological components. The indicated trend is popular and widely used in the design of educational institutions of a new generation in the following aspects:

- Cooperation of functions (Fig. 4);

- Various age groups (Fig. 4);

- Architectural planning techniques and approaches (Fig. 4, 5, 7);

- Architectural volume and landscape (Fig. 5 and 7).

A vivid example of this trend can be called the experience of the Netherlands in creating the socalled "extended schools" - public schools. The object is an example of the implementation of the "guardianship concept", according to which the system of extracurricular education in the Netherlands works [17, 18, 19] (Fig. 4).

An illustration of the cooperation of architecturalplanning techniques and the cooperation of architectural volume and landscape is the project of the qualification level "bachelor" developed at the 

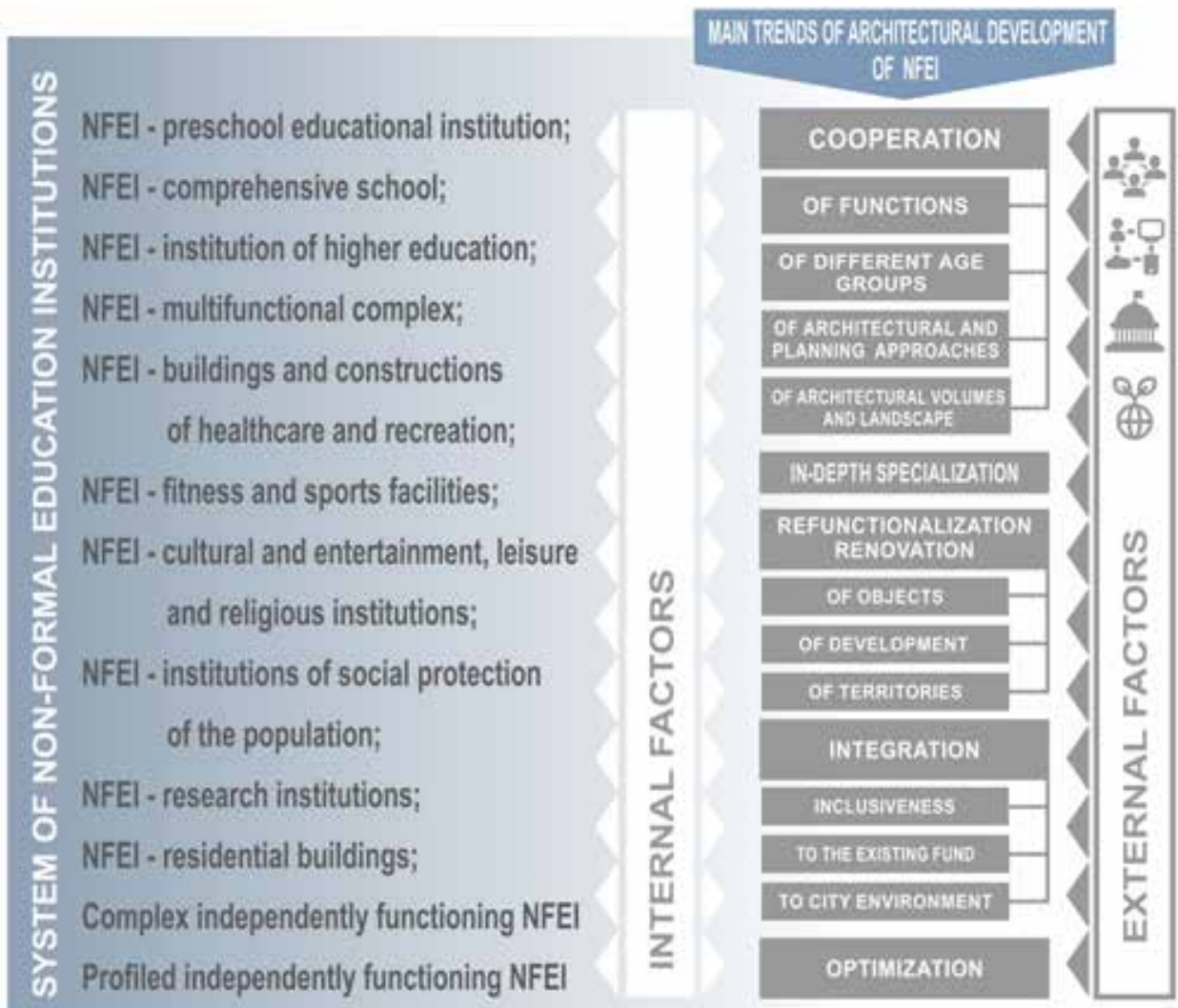

Fig. 3. Main trends of architectural development of non-formal education institutions (NFEI). Source: the scheme developed by Iryna L. Kravchenko according to own research results.
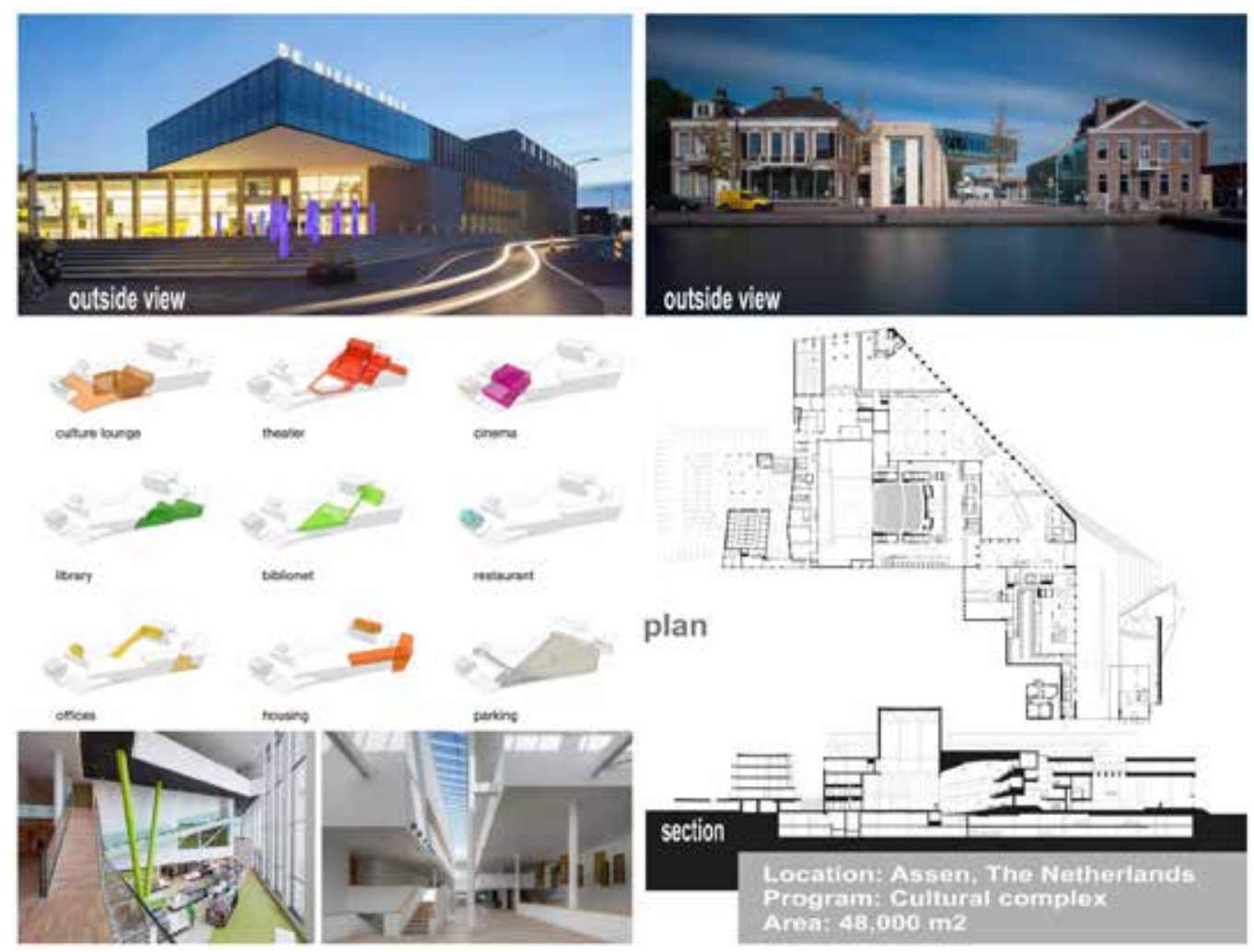

Fig. 4. Culture Complex "De Nieuwe Kolk". Architects "De Zwarte Hond", Netherlands. Source: the scheme developed by Iryna L. Kravchenko according to [17, 18]. 
Department of Architecture Theory of KNUCA (Kyiv National University of Construction and Architecture), which was performed by A. Malashenko on the theme "School of Arts in Kiev". In addition to taking into account internal factors, the project focuses on the environmental component of the building. The architectural volume optimally inscribed in the urban planning situation, with a sufficiently developed composition of the premises, remains a fairly compact structure. The space-planning structure of the building of the school of art allows you to create all the rooms for classes around the compositional and spatial coreatrium, which serves as a public media library and the main communicative node of the building. The project widely uses the method of flowing space, due to which the environment is also involved in the functional component of the school (Fig. 5).
The next trend is in-depth specialization. The term was proposed by the author and defines the saturation of the existing architectural and typological links of educational institutions with new functions that enhance the educational component of the institution by adding facilities that allow not only extracurricular activities, but also various activities for the implementation of adult education, introducing the world concept of "lifelong education". So, since the educational institution already has a certain specialization, the addition of functional groups of rooms deepens precisely the educational specialization, making it wider and more accessible to a wider circle of consumers of various educational services. In this trend, the following links of the system of non-formal educational institutions (NFEI) are considered: NFEI - a preschool educational institution, especially in the case of embedding or

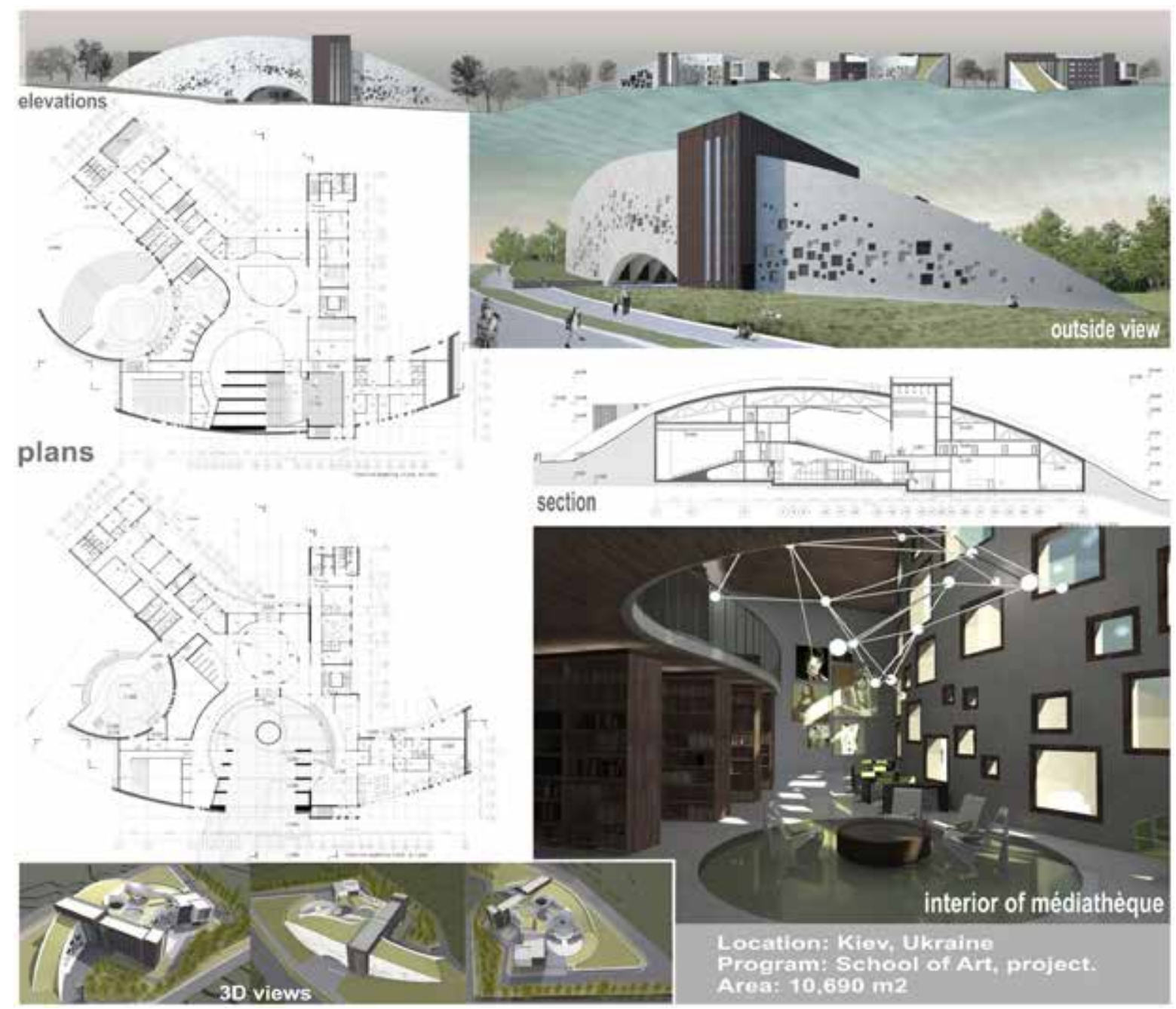

Fig. 5. The diploma project qualification level "Bachelor" - School of Arts in the city of Kyiv. Complied with student ABS-53a Malashenko A.D. Fragment of the project. The Department of Theory of Architecture of KNUCA, Kyiv, 2013. Leader: architect, Ph.D., associate professor Kravchenko I.L.

Source: the scheme developed by Iryna L. Kravchenko according to the project of Malashenko A.D. 
extension of children's preschool institutions; NFEIcomprehensive school; NFEI - institution of higher and vocational education; NFEI - institutions of social protection of the population; NFEI - research institutions; NFEI - fitness and rehabilitation institutions. The main factors influencing this trend are socio-economic, technical, urban planning and architectural-planning in terms of typological compliance and functional-planning schemes.

The next trend, which is being considered, is due to the modern transformations of society and the functioning of architectural objects, is renovation/ refunctionalization (see Fig. 3). This trend in the current study is considered and formed at three basic levels: architectural object, development, territory. The trend is due to the action of such influence factors: socio-economic in terms of the economic aspect; environmental, in the aspect of adaptation of abandoned objects and territories to educational and public institutions; urban planning; aesthetic, when the presence of historical or former industrial buildings and structures in the complex of the educational institution creates additional aesthetic appeal of the object of the educational institution. The project of the qualification level "master" developed at the Department of Architecture Theory of KNUCA, which was completed by V. Muleeva on the topic "Methods of the renovation of children's out-ofschool establishments in the conditions of historical development", presents a solution that allows using the certain means of renovation (reconstruction) to integrate the art school into the historical development of Kiev (Fig. 6).

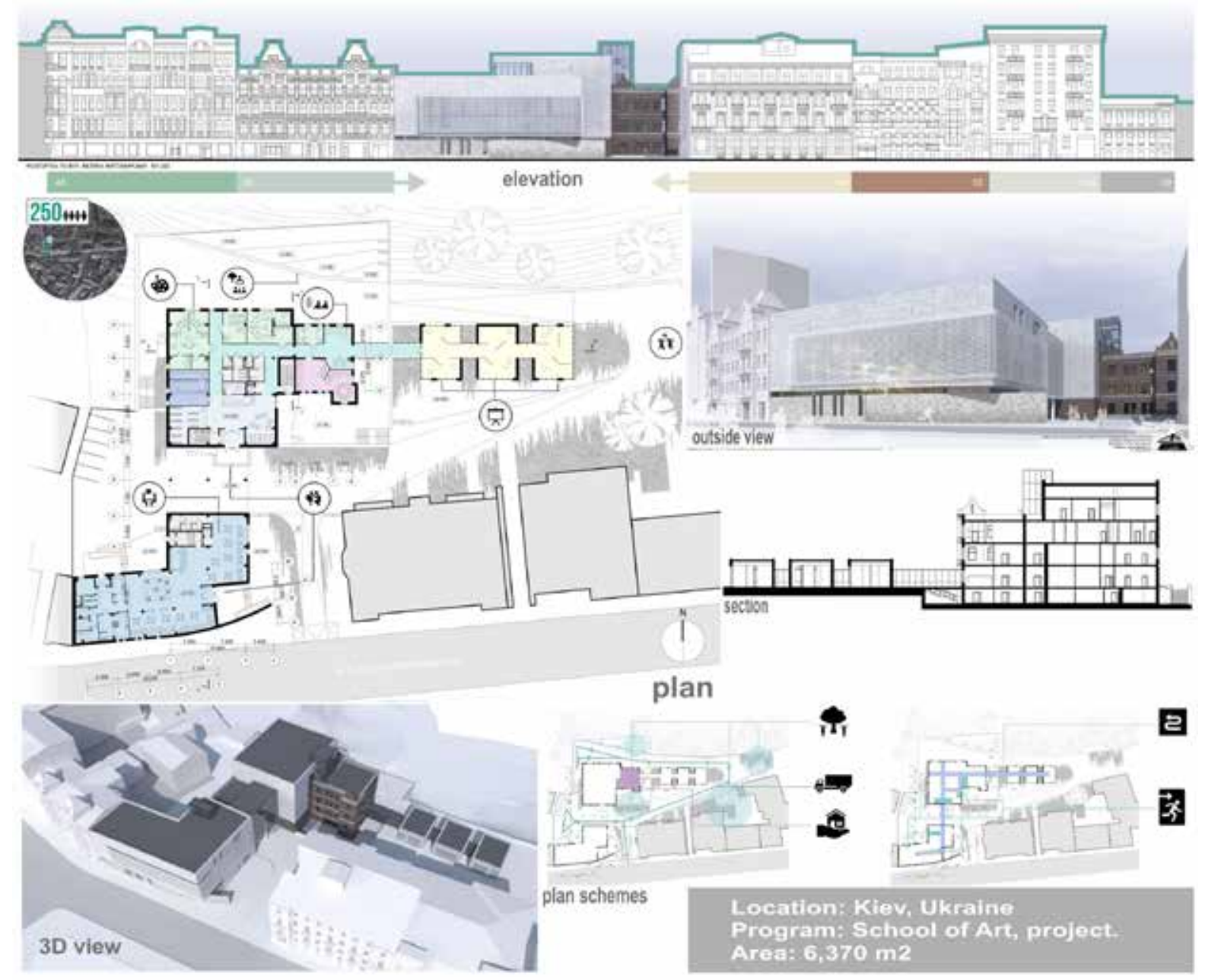

Fig. 6. The diploma project qualification level "master" - Methods of the renovation of children's out-of-school establishments in the conditions of historical development. Complied with student ABS-63 Muleeva V.G. Fragment of the project. The Department of Theory of Architecture of KNUCA, Kyiv, 2016.

Leaders: architect, Ph.D., associate prof. Kravchenko I.L., assistant lecturer Gershuni O.M.

Source: the scheme developed by Iryna L. Kravchenko according to master degree project of Muleeva V.G. 
Today, the concept of complex reconstruction, as an attempt to generalize its methods and techniques, is the leading direction in the implementation of the global concept of sustainable development and sustainable human settlements, focused on the preservation and return of restored architecture to the urban environment. In modern architectural theory and practice, methods of carrying out complex reconstruction are divided into two groups: intensive, those that do not need to expand the territory of the city and its parts; and extensive, requiring the expansion of territories. Construction in historical, protected areas requires quite serious adaptation to the site on the one hand and a clear distinction between new and existing houses on the other, since any changes in the historical environment would be noticeable enough for the appearance of the city [20,21].

Such a tendency as integration in the context of the current research is defined in the following aspects:

- The inclusiveness of educational institutions. In Ukraine, the issue of the accessibility of educational institutions for use by persons with special educational needs is still relevant. And although normative documents already exist that oblige designers to create educational institutions accessible to everyone; they basically regulate the sizes of certain architectural elements. But, it is necessary to review in each individual case, the functional planning scheme in such a way as to ensure not only the physical accessibility of persons with special educational needs, but also the full stay of such users in an educational institution. This means that additional facilities should be provided for recreation and rehabilitation activities and for staff who specialize in such problems. Ergonomics issues, in this case, are crucial along with the functional planning component;

- Integration of additional functions and facilities to the existing fund of educational institutions. This position closely intersects with renovation and refunctionalization. There are buildings

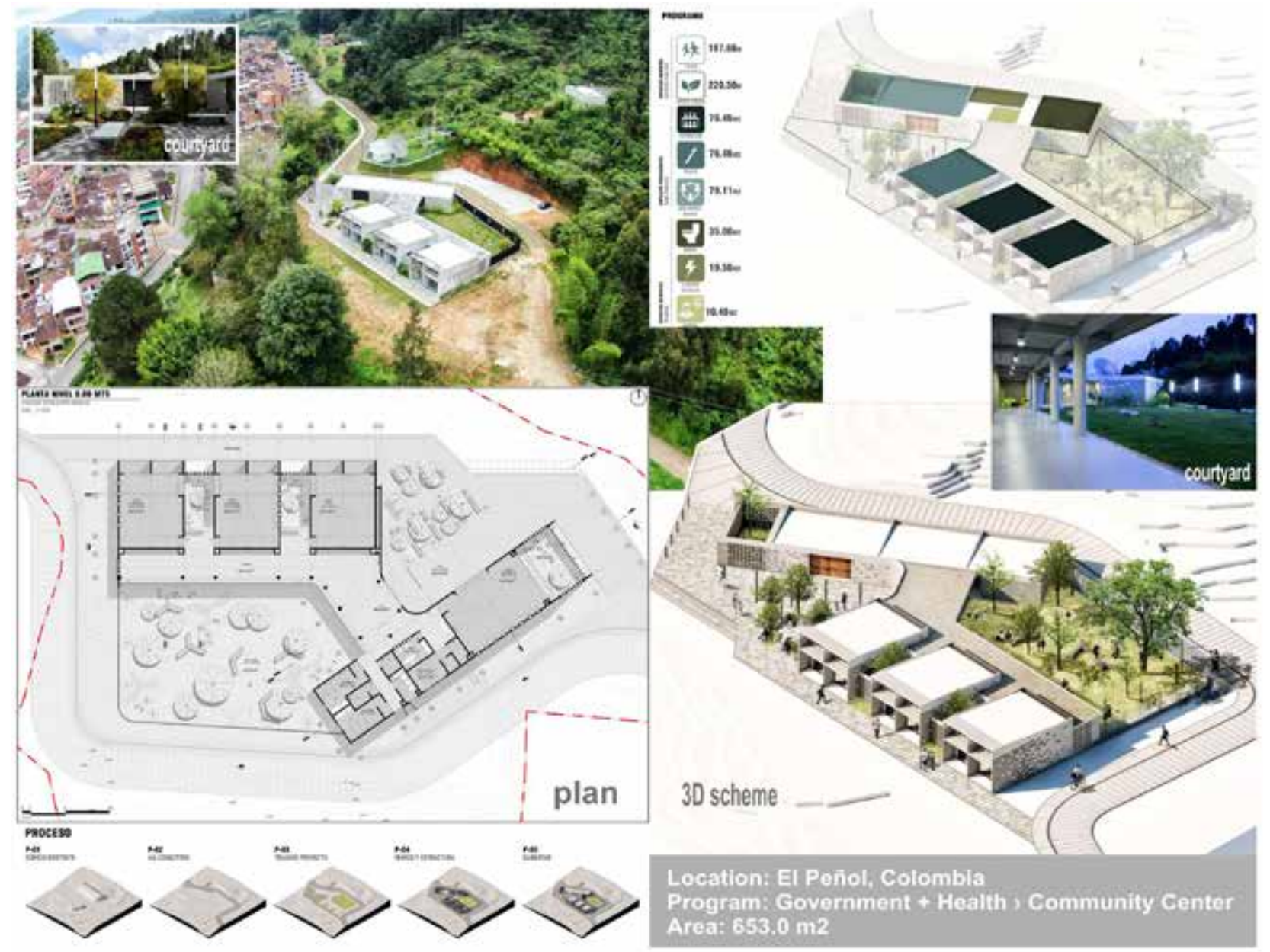

Fig. 7. "Raíces Educational Park” from TAP Taller Piloto Arquitectos, Colombia.

Source: the scheme developed by Iryna L. Kravchenko according to [22, 23$].$ 
where NFEI successfully operate together with the main purpose; this is a matter of schedule. But, this approach provides the educational needs of small (up to 20 people) and teeny (up to 7 people) user groups at the same time. In the case of an increase in groups, the question arises of the functional reorganization of the institution building. Built-in and attached building blocks for additional educational functions are appeared;

- Integration into the structure of the city, in the existing urban environment. We are talking about the construction of new integrated and specialized institutions, the renovation of existing and the integration of educational centers of a new type in the structure of the city (see Figs. 6 and 7). There are questions about the revision of the standard service radius in order to evenly provide potential users with non-formal education services.

As an illustration of this trend the Raíces Educational Park in Columbia is presented (see Fig. 7). As the architect is saying, the location of the project is in the urban perimeter that makes it a visual icon of the municipality, strengthening the values and traditions supported in an open and collective public space, a scenario of integration, for the creation of an identity and appropriation of it. Within the project the pedagogical and cultural spaces are their most important value in the vacuum that complements them, free and flexible spaces suitable for the meeting, formed from yards and gardens allowing extending their activities to the common space as an area to share. Landscape as primary material is an integral part of spatial construction, taking light and shadow, air, vegetation and the landscape itself which is intrinsic part of the site. The project is in a natural context of transition between urban and rural, this is built from materials and finishes in sight. The Educational Park becomes a space that recognizes its own landscape, showing it with the capacity and the kindness to receive the activities and experiences [22, 23].

The next trend that is being considered is the optimization of design decisions. Such a trend is formed under the influence of a socio-economic factor in the aspect of feasibility and economic reasonableness of certain design decisions; technical and political factors in the context of the formation of new types of educational-public buildings; architectural-planning and aesthetic factors. The indicated trend mainly concerns the spatial and structural-functional solutions of the architectural object of the institution of additional education. Due to the increase and complication of relations between premises and groups of premises, the question of the reorganization and optimization of sustainable functional schemes arises. So, for example, the functions of libraries in the structure of educational institutions are expanding and, under the influence of a technical factor, are enriched, reviewed and the médiathèques are formed. The methods of organizing the general educational space as a communicative and educational component are widely used. With the formation of médiathèques and a combination of various groups of educational premises and blocks such space is organise, more often, as the atrium space (see Figs. 4 and 5).

Of course, one cannot say that each tendency mentioned above exists and develops separately from others. All the considered trends are interconnected and complement each other. The author has identified and grouped the development trends of the NFEI architecture in such a way as to show the relationship of the influence of external and internal factors on specific trends and design techniques of non-formal education institutions and, thereby, adjust their educational scenarios.

\section{CONCLUSION}

Non-formal education (out-of-school education, adult and elderly education, etc.) is, today, one of the decisive mechanisms of the social environment for the full organization of free time, education on interests and needs, creative development and formation of useful skills and competencies, as well as their successful implementation. The design of non-formal education institutions in our time must meet the many requirements and factors, both of external and internal impact.

The most influential category of external factors is the socio-economic, especially in the sociodemographic, socio-professional, socio-territorial aspects. The economic aspect, in addition to the issues of forming the educational material base of educational institutions, is very important in the context of the modern development of the human factor. The technological factor affects both the mechanisms of education and the creation of new types of informative educational space. The political factor in the field of globalization of education, decentralization of power and educational reforms should be reflected in functional scenarios and 
structural models of non-formal education buildings. The environmental influence factor now obliges all architectural objects, both new buildings and the existing foundation, to meet modern requirements for preserving the environment.

The architectural objects and experimental graduation projects presented for analysis illustrate the influence of external and internal factors on the architecture of non-formal education institutions, as well as the main trends in the development of architecture of educational buildings of a new type.

The main trends in the development of the architecture of non-formal educational institutions, such as cooperation, in-depth specialization, renovation or refunctionalization, integration and optimization were selected. Such trends were highlighted by the author on the basis of the analysis of foreign experience in designing institutions of additional education and according to the results of experimental design at the Department of Architecture Theory of Kyiv National University of Construction and Architecture.

The buildings of the non-formal education institutions that are optimal in terms of the functioning scenario and that are compositionally balanced should contribute to the restoration or acquisition of the necessary competencies, because the space for learning is a component of this learning process and, in our time, already has an informative function.

\section{REFERENCES}

[1] Cullen J.: 'Going Lifelong Learning': critical factors for the development of Lifelong Learning Centres Tavistock Institute, Arcola Research LLP, UK, p. 39.

[2] Bykovskaya O.V.: Out-of-school education: theoretical and methodological foundations, EPC ALCON, Kiev 2008, p. 336.

[3] Pavlik N.: Teoriya i praktyka orhanizatsiyi neformal'noyi osvity molodi (Theory and practice of organizing non-formal youth education), Publishing House Ivan Franko Zhytomyr State University, 2017, p. 162.

[4] Chahrak N.: Influence of demographic and socio-economic factors on the development of older adult education in the USA, Visnyk, Taras Shevchenko National University of Kyiv, "Pedagogy" 2016, 2(4), ISSN 2415-3699, pp. 77-83.

[5] Verbets V.V., Subot O.A., Khristyuk T.A.: Sociology: Study Guide, ISBN 978-966-351-222-8, CONDOR, 2009, p. 550 .

[6] Smirnov V.: Navchannya protyahom zhyttya: vid 1920-kh do s'ohodennya (Life-long learning: from the 1920s to the present), Psychological-pedagogical problems of a rural school: a collection of scientific works of the Pavel Tychyna Uman State Pedagogical University, FOP Zhovtyy O.O., Issue 43, 2012, pp. 342-348.

[7] Jeffery A. Lackney: PhD AIA University of Wisconsin-Madison. 33 Educational Design Principles for Schools and Community Learning Centers, Updated: August, 2007, retrived 28.09.2019 [https://schoolstudio.typepad.com/ school design studio/33-educational-design-pri.html].

[8] Baker L.: A History of School Design and its Indoor Environmental Standards, 1900 to Today. National Clearinghouse for Educational Facilities a program of the National Institute of Building Sciences, 2012, retrived 28.09.2019 [http:// www.ncef.org/pubs/greenschoolshistory.pdf].

[9] Habibe Acar. Learning Environments for Children in Outdoor Spaces. Department of Landscape Architecture, Faculty of Forestry, Karadeniz Technical University, 2014, DOI; https://doi.org/10.1016/j.sbspro.2014.05.147, retrived 28.09.2019 [https:/www.sciencedirect.com/science/article/pii/S187704281403571X?via\%3Dihub\#!].

[10] Abyzov V.: The main factors and conditions of sustainable development. Sastainable design as the paradigm of the space in the XXI century, Kielce University of Technology, 2016, pp. 19-26.

[11] Abyzov V.: Modern Conditions and the Impact of the Creation of Architectural Environment, "Material Science \& Engineering - IOP", Vol. 245, World Multidisciplinary Civil Engineering-Architecture-Urban Planning Symposium, WMCAUS, 12-16 June 2017, Prague, Czech Republic, published online 4 November, Bristol 2017, DOI:10.1088/1757-899X/245/8/082050, p. 12.

[12] Kravchenko I.L.: Impact of socioeconomic factor on architectural formation of buildings for non-formal education in Ukraine. s p a c e \& FORM '39_2019, "Space and Form: Scientific journal of Polish Academy of Sciences and West Pomeranian University of Technology” 2019, No. 39, Szczecin, pp. 45-56, e-ISSN 2391-7725, ISSN 18953247 (Index Copernicus Value), DOI: 10.21005/pif.2019.39.B-02.

[13] Abankina T.V.: Integratsii i kooperatsii obrazovatel'nykh uchrezhdeniy i organizatsiy sotsial'no-kul'turnoy sfery (Integration and cooperation of educational institutions and socio-cultural organizations): National Research University Higher School of Economics, Institute of Education, Moscow, Russia 2015, retrieved 03.08.2019 [https:// publications.hse.ru/mirror/pubs/share/folder/d1zc5j1zs8/direct/98177364].

[14] Kalinichenko D.R.: Hlobal'nyy rynok pratsi: suchasni vyklyky dlya rozvytku lyuds 'koho kapitalu (Global labour market: modern challenges for the human capital development), "Scientific Bulletin of the International Humanities University”, series: Economics and Management, Vol. 25 (2), Odessa 2017, access mode: http://nbuv.gov.ua/UJRN/ Nvmgu_eim_2017_25(2)_15,pp. 60-65. 
[15] Sbruyeva A.A.: Hlobalizatsiya osvity (Globalization of Education), Encyclopedia of Education/Acad. ped. Sciences of Ukraine; main edit. V.H. Kremen, K.: Yurinkom Inter, 2008, pp. 136-137.

[16] Byuleten' reyestratsiyi naukovo-doslidnikh ta doslidno-konstruktors' kykh robit (NDR ta DKR) - periodichne vydannya (Bulletin of research and development (R \& D) - periodical), ISSN 2522-4158, Ukrintei, Kiev 2018, 97, p., No. 67.01.18.0768/0117У005420, p. 55.

[17] Culture Complex De Nieuwe Kolk/De Zwarte Hond; architects: Jurjen van der Meer, Tjeerd Jellema, retrieved 03.08.2019 [https://www.archdaily.com/514880/culture-complex-de-nieuwe-kolk-de-zwarte-hond].

[18] Large culture cluster connects old and new, large and small-scale, retrieved 03.08.2019 [https://www.dezwartehond. $\mathrm{nl} / \mathrm{en} / \mathrm{projecten/cultureel-kwartier-de-nieuwe-kolk].}$

[19] Merylova I.O.: Variants of extracuricular educational network's development in Ukraine on the base of world concepts' analysing, Visnuk Pridneprovs'ka State Academy of Civil Engineering and Architecture, 2015, No. 2 (203), ISSN 2312-2676, pp. 52-63.

[20] Kravchenko I.L., Gershuni O.M., Muleeva V.G.: Metody renovatsiyi dytyachykh pozashkil'nykh zakladiv ta yikh terytoriy v umovakh istorychnoyi zabudovy (Methods of renovation of extracurricular institutions and their territories in the conditions of historical development), I.L. Kravchenko, O.M. Gershuni, V.G. Muleeva, Modern problems of architecture and urban planning, 2016, Vol. 46, access mode: http://nbuv.gov.ua/UJRN/Spam_2016_46_77, pp. 419-423.

[21] Kravchenko I.L., Muleeva V.G.: Tendentsiyi rozvytku dytyachykh pozashkil'nykh zakladiv (Trends of development of children's out-of-school institutions), I.L. Kravchenko, V.G. Muleeva, Modern problems of architecture and urban planning, 2016, Vol. 44, access mode: http://nbuv.gov.ua/UJRN/Spam_2016_44_39, pp. 267-272.

[22] Raices Educational Park/Taller Piloto Arquitectos, retrieved 03.08.2019 [https://www.archdaily.com/870235/raiceseducational-park-taller-piloto-arquitectos].

[23] Raices Educational Park, El Peñol, Colombia, retrieved 03.08.2019 [https://architizer.com/projects/raiceseducational-park-4/].

\section{Acknowledgments:}

TThe work was financed by the Kiev National University of Construction and Architecture, Architecture, Architectural faculty, Departament of the Architectural Theory

\section{Podziękowania:}

Praca byta finansowana przez Kijowski Krajowy Uniwersytet Budownictwa i Architektury Wydzial Architektoniczny. Wydziat Teorii Architektury, Ukraina 